\title{
Analysis of the Contribution of the Agricultural Sector to the GRDP Value of Dairi Regency, North Sumatra Province
}

\section{Analisis Kontribusi Sektor Pertanian terhadap Nilai PDRB Kabupaten Dairi Provinsi Sumatera Utara}

\author{
Marliyah'); Muhammad Syahbudi2); Lisna Limbong ${ }^{2)}$ \\ 1,2) Fakultas Ekonomi dan Bisnis Islam, Universitas Islam Negeri Sumatera Utara \\ Email: 1) lisnalimbong611@gmail.com
}

How to Cite :

Marliyah, Syahbudi, M., Limbong, L. (2022). Analysis of the Contribution of the Agricultural Sector to the GRDP Value of Dairi Regency, North Sumatra Province. Jurnal Ekonomi Manajemen Akuntansi Dan Keuangan, 3(1). DOI: https://doi.org/10.53697/emak.v3i1

ARTICLE HISTORY

Received [30 Desember 2021]

Revised [02 Januari 2021]

Accepted [20 Januari 2022]

\section{KEYWORDS}

Dairi Regency, Agriculture

Sector, GRDP.

This is an open access article under the $C C-B Y$-SA license

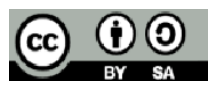

\section{ABSTRAK}

Sektor pertanian di Kabupaten Dairi merupakan sektor strategis yang mempunyai keterkaitan erat dengan pengurangan kemiskinan, upaya mengatasi pengangguran, usaha membangun ketahanan pangan, memproduksi pangan, usaha pelestarian lingkungan dan basis pembangunan ekonomi daerah.Selain itu, menurut Badan Pusat Statistik Kabupaten Dairi, sektor pertanian memberikan distribusi persentase yang tertinggi terhadap Produk Domestik Regional Bruto (PDRB) dari tahun 2014-2018 dibandingkan sektor lainnya. Penelitian ini bertujuan untuk meneliti tentang seberapa besar kontribusi sektor pertanian terhadap Produk Domestik Regional Bruto (PDRB) di Kabupaten Dairi dan untuk mengetahui seberapa besar proyeksi pertumbuhan kontribusi sektor pertanian pada tahun 2025 di Kabupaten Dairi dengan jenis penelitian kuantitatif menggunakan data sekunder. Penelitian ini menggunakan data time series berbentuk data tahunan dengan rentang waktu pada tahun 20162020. Data dianalisis dengan menggunakan analisis kontribusi dan analisis trend kuandrat terkecil (least square method). Proses pengolahan data menggunakan software excel. Hasil analisis kontribusi menunjukkan bahwa kontribusi sektor pertanian terhadap Produk Domestik Regional Bruto (PDRB) Kabupaten Dairi pada tahun 2016 sebesar 46.02\%, pada tahun 2017 sebesar 45.68\%, pada tahun 2018 sebesar 45.29\%, pada tahun 2019 sebesar 44.79\%, dan pada tahun 2020 sebesar 45.19\%. Hasil analisis trend kuadrat terkecil (least square method) menunjukkan proyeksi pertumbuhan kontribusi sektor pertanian terhadap Produk Domestik Regional Bruto (PDRB) Kabupaten Dairi pada tahun 2021 sebesar 44.63\%, pada tahun 2022 sebesar 44.37\%, pada tahun 2023 sebesar 44.12\%, pada tahun 2024 sebesar $43.86 \%$ dan pada tahun 2025 sebesar $43.61 \%$.

\section{ABSTRACT}

The agricultural sector in Dairi Regency is a strategic sector that has close links with poverty reduction, efforts to overcome unemployment, efforts to build food security, food production, environmental conservation efforts and the basis of regional economic development. the distribution of the highest percentage of Gross Regional Domestic Product (GRDP) from 20142018 compared to other sectors. This study aims to examine how big the contribution of the agricultural sector to the Gross Regional Domestic 
Product (GRDP) in Dairi Regency and to find out how big the projected growth of the agricultural sector's contribution in 2025 in Dairi Regency is with quantitative research using secondary data. This study uses time series data in the form of annual data with a time span of 2016-2020. Data were analyzed using contribution analysis and least squared trend analysis (least square method). Process data processing using excel software. The results of the contribution analysis show that the contribution of the agricultural sector to the Gross Regional Domestic Product (GDP) of Dairi Regency in 2016 was 46.02\%, in 2017 it was 45.68\%, in 2018 it was 45.29\%, in 2019 it was $44.79 \%$, and in 2020 by $45.19 \%$. The results of the analysis of the least squares trend (least square method) show the projected growth of the contribution of the agricultural sector to the Gross Regional Domestic Product (GDP) of Dairi Regency in 2021 by 44.63\%, in 2022 by $44.37 \%$, in 2023 by $44.12 \%$, in 2024 by $43.86 \%$ and in 2025 by $43.61 \%$.

\section{PENDAHULUAN}

Pertanian merupakan tumpuan perekonomian Indonesia. Meskipun kontribusi relatif pertanian terhadap perekonomian diukur sebagai proporsi nilai tambah dalam PDB (Produk Domestik Bruto) atau pendapatan nasional yang menurun dari tahun ke tahun, bukan berarti nilai dan perannya tidak signifikan. Nilai tambah sektor pertanian terus meningkat dari waktu ke waktu. Peran sektor ini dalam menyerap tenaga kerja tetap yang paling penting. Mayoritas penduduk Indonesia yang sebagian besar tinggal di pedesaan masih mengandalkan sektor pertanian untuk mata pencahariannya.

Pertanian dapat berkontribusi dalam perekonomian nasional, menghadapi dinamika dan perdagangan bebas diperlukan suatu perencanaan nasional dengan pemilihan atas dasar prioritas dan sasaran dari program pembangunan pertanian. Salah satu aspek yang cukup menentukan keberhasilan pembangunan adalah dengan mengolakasikan investasi yang sesuai dengan lokasi dan kondisi masyarakat. Pertanian dan pembangunan pedesaan memiliki potensi yang cukup besar terkait dengan masalah-masalah kontribusi terhadap perekonomian nasional melalui hasil yang diperoleh dari pendapatan domestik bruto, sehingga sektor pertanian ditempatkan pada posisi prioritas dalam perencanaan pembangunan nasional. Pembangunan pertanian di Indonesia dianggap penting dari keseluruhan pembangunan nasional. Pentingnya pertanian dalam pertumbuhan ekonomi yang dipimpin oleh sektor pertanian, dan pertumbuhan pertanian akan meningkatkan laju pertumbuhan total pendapatan daerah (PDB).

Produk Domestik Bruto (PDB) merupakan indikator makro ekonomi yang pada umumnya digunakan untuk mengukur kinerja ekonomi di suatu negara. Sedangkan untuk tingkat wilayah, baik di tingkat wilayah provinsi maupun kabupaten atau kota digunakan Produk Domestik Regional Bruto (PDRB) baik atas harga berlaku maupun atas dasar harga konstan. Nilai PDRB suatu wilayah dapat memberikan informasi tingkat pertumbuhan ekonomi maupun tingkat kemakmuran masyarakat terhadap wilayah tersebut. Semakin tinggi PDRB suatu daerah maka dapat dikatakan bahwa pertumbuhan ekonominya juga semakin tinggi, atau kesejahteraan masyarakatnya semakin baik.

Sektor pertanian di Kabupaten Dairi merupakan sektor strategis yang mempunyai keterkaitan erat dengan pengurangan kemiskinan, upaya mengatasi pengangguran, usaha membangun ketahanan pangan, memproduksi pangan, usaha pelestarian lingkungan dan basis pembangunan ekonomi daerah. Selain itu, menurut Badan Pusat Statistik Kabupaten Dairi, sektor pertanian memberikan kontribusi yang tertinggi terhadap Produk Domestik Regional Bruto (PDRB) dari tahun 2014-2018 dibandingkan dengan sektor lainnya, pada tahun 2014 sebesar 47,47\%, tahun 2015 sebesar 46,56\%, tahun 2016 sebesar 46,02\%, tahun 2017 sebesar 45,67\%, tahun 2018 sebesar 45,29\%. Meskipun tidak mengalami kenaikan setiap tahunnya, tetapi sektor pertanian memberikan 
kontribusi yang besar dibandingkan sektor lainnya. Berikut data distribusi persentase PDRB atas dasar harga konstan tahun 2010.

Tabel 1. Distribusi Persentase Produk Domestik Regional Bruto Atas Dasar Harga Konstan Tahun 2010

\begin{tabular}{|c|c|c|c|c|c|}
\hline \multirow[t]{2}{*}{ Kategori/Lapangan Usaha } & \multicolumn{5}{|c|}{$\begin{array}{c}\text { Distribusi Persentase PDRB Atas Dasar Harga } \\
\text { Konstan Tahun } 2010 \text { (Persen) }\end{array}$} \\
\hline & 2014 & 2015 & 2016 & 2017 & 2018 \\
\hline Pertanian, kehutanan dan perikanan & 47,47 & 46,56 & 46,02 & 45,67 & 45,29 \\
\hline Pertambangan dan penggalian & 0,07 & 0,07 & 0,07 & 0,07 & 0,07 \\
\hline Industri pengolahan & 0,33 & 0,33 & 0,33 & 0,33 & 0,33 \\
\hline Pengadaan listrik dan gas & 0,09 & 0,09 & 0,09 & 0,09 & 0,09 \\
\hline $\begin{array}{l}\text { Pengadaan air, pengelolaan sampah, } \\
\text { limbah dan daur ulang }\end{array}$ & 0,09 & 0,09 & 0,09 & 0,09 & 0,09 \\
\hline Konstruksi & 12,21 & 12,42 & 12,66 & 12,86 & 12,97 \\
\hline $\begin{array}{l}\text { Perdagangan besar dan eceran, reparasi } \\
\text { mobil dan sepeda motor }\end{array}$ & 15,49 & 15,96 & 16,38 & 16,56 & 16,69 \\
\hline Transportasi dan pergudangan & 3,57 & 3,63 & 3,68 & 3,75 & 3,82 \\
\hline Penyediaan akomodasi dan makan minum & 2,87 & 2,93 & 2,99 & 2,99 & 2,99 \\
\hline Informasi dan komunikasi & 1,18 & 1,16 & 1,14 & 1,14 & 1,15 \\
\hline Jasa keuangan dan asuransi & 2,02 & 2,07 & 2,04 & 2,03 & 2,01 \\
\hline Real estat & 2,70 & 2,67 & 2,62 & 2,66 & 2,67 \\
\hline Jasa perusahaan & 0,06 & 0,06 & 0,06 & 0,06 & 0,06 \\
\hline $\begin{array}{l}\text { Administrasi pemerintahan pertahanan } \\
\text { dan jaminan sosial wajib }\end{array}$ & 9,36 & 9,44 & 9,28 & 9,13 & 9,20 \\
\hline Jasa pendidikan & 1,86 & 1,87 & 1,90 & 1,91 & 1,92 \\
\hline Jasa kesehatan dan kegiatan sosial & 0,62 & 0,62 & 0,62 & 0,64 & 0,64 \\
\hline Jasa lainnya & 0,02 & 0,02 & 0,02 & 0,02 & 0,02 \\
\hline PRODUK DOMESTIK REGIONAL BRUTO & 100,00 & 100,00 & 100,00 & 100,00 & 100,00 \\
\hline
\end{tabular}

Sumber: BPS Kabupaten Dairi

Berdasarkan informasi tentang perkembangan Produk Domestik Regional Bruto Kabupaten Dairi tahun 2014-2018, dapat diketahui bahwa distribusi persentase sektor pertanian terhadap PDRB setiap tahunnya turun. Hal ini menunjukkan bahwa ada kecenderungan terjadinya proses transformasi struktural perekonomian dan perubahan/pergeseran peranan sektor pertanian di Kabupaten Dairi. Sedangkan menurut pemikiran teori pembangunan modern, kontribusi sektor pertanian terhadap pembentukan PDB akan semakin berkurang dengan semakin majunya perekonomian suatu negara atau wilayah, tetapi penurunan kontribusi tersebut akan terkompensasi oleh peningkatan kontribusi sektor lain (sekunder atau tersier). Penurunan kontribusi sektor pertanian dalam pembentukan PDB seharusnya juga diikuti oleh penurunan peran sebagai penampung tenaga kerja. Sedangkan penduduk di Kabupaten Dairi yang bekerja pada Agustus 2017 mayoritas bekerja pada sektor pertanian dengan jumlah tenaga kerja mencapai 71,78 persen. Berikut data persentase penduduk di Kabupaten Dairi yang bekerja di sektor pertanian.

Tabel 2. Persentase Penduduk di Kabupaten Dairi Bekerja di Sektor Pertanian Tahun 2017-2020 (\%)

\begin{tabular}{|c|c|c|c|c|}
\hline Tahun & 2017 & 2018 & 2019 & 2020 \\
\hline Persentase & $71.78 \%$ & $70.95 \%$ & $70.00 \%$ & $73.49 \%$ \\
\hline
\end{tabular}

Sumber: BPS Kabupaten Dairi 
Berdasarkan informasi dari tabel diatas diketahui bahwa persentase penduduk di Kabupaten Dairi mayoritas bekerja di sektor pertanian dengan angka persentase mencapai 70.00\%. Dari tabel diatas juga diketahui walaupun pada tahun 2018 dan tahun 2019 persentase penduduk berkurang sebesar 0.95\%, namun pada tahun 2020 naik signifikan sebesar 3.49\% menjadi 73.49\%. Data ini menunjukkan bahwa sektor pertanian merupakan penampung tenaga kerja terbesar di Kabupaten Dairi dan dapat menurunkan tingkat angka penggangguran di Kabupaten Dairi. Hal ini juga ditunjukkan berdasarkan luas lahan pertanian di Kabupaten Dairi yang berfluktuasi cenderung naik. Berikut data luas lahan pertanian di Kabupaten Dairi tahun 2016-2020.

Tabel 3. Total Luas Penggunaan Lahan di Kabupaten Dairi Tahun 2016-2020 (Hektar)

\begin{tabular}{|c|c|c|c|}
\multirow{2}{*}{ Tahun } & \multicolumn{2}{|c|}{ Penggunaan Lahan } & Total Luas Lahan \\
\cline { 2 - 3 } & Pertanian & Bukan Pertanian & \\
\hline 2016 & 153.069 & 39.711 & 192.780 \\
\hline 2017 & 157.324 & 31.098 & 188.422 \\
\hline 2018 & 160.746 & 32.034 & 192.780 \\
\hline 2020 & 156.549 & 36.231 & 192.780 \\
\hline
\end{tabular}

Sumber: Dinas Pertanian Kabupaten Dairi

Tabel 2 dan tabel 3 menunjukkan bahwa sektor pertanian dapat diyakini sebagai intisari pembangunan di Kabupaten Dairi berdasarkan data persentase tenaga kerja di Kabupaten Dairi mayoritas bekerja di sektor pertanian dengan rata-rata sebesar $71.55 \%$ dan penggunaan lahan di Kabupaten Dairi mayoritas digunakan sebagai lahan pertanian dan luas lahan pertanian di Kabupaten Dairi cenderung meningkat dari tahun 2016-2020. Namun, data ini tidak diikuti dengan data kontribusi sektor pertanian di Kabupaten Dairi yang mengalami penurunan dari tahun 20142018.

\section{Pertumbuhan Ekonomi}

\section{LANDASAN TEORI}

Secara umum, ekonom melihat pertumbuhan ekonomi sebagai kenaikan output perkapita dalam jangka panjang. Hal ini dapat ditemukan dalam pemikiran Sukirno dan Simon Kuznets, yang menjelaskan pertumbuhan ekonomi sebagai kenaikan kemampuan suatu negara untuk menyediakan berbagai jenis barang ekonomi kepada penduduknya, sesuai dengan kemajuan teknologi, dan penyesuaian kelambagaan dan ideologi sehingga inovasi yang dihasilkan dapat dimanfaatkan secara tepat. Dengan demikian, pertumbuhan ekonomi sangat identik dengan perubahan kuantitatif seperti pertambahan produksi barang industri, infrastruktur, jumlah sekolah, yang kesemuanya itu dihitung sebagai Produk Domestik Bruto (PDB).

Produk Domestik Bruto (PDB) merupakan nilai pasar dari semua barang dan jasa final yang diproduksi dalam sebuah Negara pada suatu periode, meliputi faktor produksi milik warga negaranya sendiri maupun milik warga negara asing yang melakukan produksi di dalam negara tersebut. PDB merupakan salah satu instrumen penting untuk dapat menghitung pendapatan nasional. Dengan pendapatan nasional, akan terlihat tingkat kemakmuran suatu negara, semakin tinggi pendapatan nasional suatu Negara maka dapat dikatakan semakin tinggi juga tingkat kesejahteraan rakyatnya.

\section{Pembangunan Ekonomi Daerah}

Pembangunan ekonomi daerah adalah suatu proses yang mencakup pembentukan institusiinstitusi baru, pembangunan industri-industri alternatif, perbaikan kapasitas tenaga kerja yang ada untuk menghasilkan produk dan jasa yang lebih baik, identifikasi pasar-pasar baru, alih pengetahuan dan teknologi, serta pengembangan usaha-usaha baru.

Tujuan utama dari setiap pembangunan ekonomi daerah adalah untuk meningkatkan 
jumlah dan jenis peluang kerja untuk masyarakat daerah. Untuk mencapai tujuan tersebut, pemerintah daerah dan masyarakatnya harus secara bersama-sama mengambil inisiatif pembangunan daerah. Oleh karena itu, pemerintah daerah dengan partisipasi masyarakatnya, dengan dukungan sumberdaya yang ada harus mampu menghitung potensi sumberdayasumberdaya yang diperlukan untuk merancang dan membangun ekonomi daerahnya.

\section{Produk Domestik Regional Bruto (PDRB)}

Produk Domestik Regional Bruto (PDRB) merupakan salah satu indikator penting untuk mengetahui kondisi ekonomi disuatu daerah dalam suatu periode tertentu, baik atas dasar harga berlaku maupun atas dasar harga konstan. PDRB pada dasarnya merupakan jumlah nilai tambah yang dihasilkan oleh seluruh unit usaha dalam suatu daerah tertentu, atau merupakan jumlah nilai barang dan jasa akhir yang dihasilkan oleh seluruh unit ekonomi pada suatu daerah. PDRB atas harga berlaku menggambarkan nilai tambah barang dan jasa yang dihitung menggunakan harga pada tahun berjalan, sedangkan PDRB atas dasar harga konstan menunjukkan nilai tambah barang dan jasa tersebut yang dihitung menggunakan harga yang berlaku pada satu tertentu sebagai tahun dasar. PDRB menurut harga berlaku digunakan untuk mengetahui kemampuan sumber daya ekonomi, pergeseran dan struktur ekonomi suatu daerah. Sementara itu, PDRB harga konstan digunakan untuk mengetahui pertumbuhan ekonomi secara riil dari tahun ke tahun atau pertumbuhan ekonomi yang tidak dipengaruhi oleh faktor harga. Laju pertumbuhan ekonomi merupakan suatu indikator ekonomi makro yang menggambarkan seberapa jauh keberhasilan pembangunan suatu daerah dalam periode waktu tertentu. Dengan demikian indikator ini dapat pula dipakai untuk menentukan arah kebijakan pembangunan yang akan datang.

\section{Pertumbuhan Ekonomi dalam Perspektif Islam}

Pembangunan ekonomi memegang peranan yang sangat penting bagi sebuah negara. Walaupun istilah pembangunan ekonomi tidak dikenal dalam masa Islam awal, tetapi Rasulullah sangat menjunjung tinggi ekonomi rakyat, suka melihat umat Islam hidup berkecukupan daripada dalam keadaan miskin dan kelaparan, dan sangat menginginkan umatnya berada pada level tertinggi pembangunan.

Penekanan disini ialah bahwa pertumbuhan ekonomi telah ada dalam wacana pemikiran Muslim klasik, yang dibahas dalam "pemakmuran Bumi" yang merupakan pemahaman dari firman Allah QS. Hud (11) ayat 61:

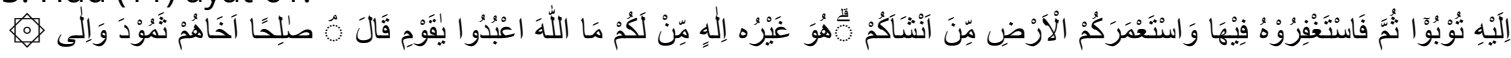

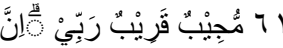

Artinya: Kepada (kaum) Samud (Kami utus) saudara mereka, Saleh. Dia berkata, "Wahai kaumku, sembahlah Allah! Sekali-kali tidak ada tuhan bagimu selain Dia. Dia telah menciptakanmu dari bumi (tanah) dan menjadikanmu pemakmurnya. Oleh karena itu, mohonlah ampunan kepadaNya, kemudian bertobatlah kepada-Nya. Sesungguhnya Tuhanku sangat dekat lagi Maha Memperkenankan (doa hamba-Nya)."

Terminologi "pemakmuran tanah" mengandung pemahaman tentang pertumbuhan ekonomi, sebagaimana dikatakan oleh Ali Bin Abi Thalib kepada seorang gubernurnya di Mesir: "Hendaklah kamu memperhatikan pemakmuran tanah dengan perhatian yang lebih besar daripada orientasi pemungutan pajak, karena pajak sendiri hanya dapat dioptimalkan dengan pemakmuran tanah. Barangsiapa yang memungut pajak tanpa memperhatikan pemakmuran tanah, Negara tersebut akan hancur."

Beberapa pemahaman pokok mengenai pertumbuhan ekonomi yang dilihat dari perspektif Islam diantaranya mengenai batasan tentang persoalan ekonomi. Perspektif Islam tidaklah sama dengan yang dianut oleh kapitalis, dimana yang dimaksud dengan persoalan ekonomi yaitu persoalan kekayaan dan minimnya sumber-sumber kekayaan. Perspektif Islam menyatakan bahwa hal itu sesuai dengan kapasitas yang telah disediakan oleh Allah untuk memenuhi kebutuhan manusia yang ditujukan untuk mengatasi persoalan kehidupan manusia. 


\section{Sektor Pertanian}

Transformasi struktural perekonomian Indonesia menuju ke corak yang industrial tidak dengan sendirinya melenyapkan nuansa agraritasnya. Berbagai teori pertumbuhan ekonomi klasik dan studi empiris Bank Dunia menunjukkan, bahwa sukses pengembangan sektor industri di suatu negara selalu diiringi dengan perbaikan produktivitas dan pertumbuhan berkelanjutan di sektor pertanian. Selain menyediakan kebutuhan pangan bagi penduduk serta menyerap tenaga kerja, sektor pertanian juga merupakan pemasok bahan baku bagi sektor industri dan menjadi sumber penghasil devisa.

Sektor pertanian yang dimaksudkan dalam konsep pendapatan nasional menurut lapangan usaha atau sektor produksi ialah pertanian dalam arti luas. Di Indonesia, sektor pertanian dalam arti luas ini dipilah-pilah menjadi lima subsektor yaitu: subsektor tanaman pangan, subsektor perkebunan, subsektor kehutanan, subsektor peternakan, dan subsektor perikanan.

\section{Hubungan Sektor Pertanian terhadap Produk Domestik Regional Bruto (PDRB)}

Pentingnya pertanian di dalam pertumbuhan sebuah ekonomi yang didominasi oleh sektor pertanian, pertumbuhan pertanian akan meningkatkan laju pertumbuhan pendapatan daerah bruto (PDB). Peran sektor pertanian sangat diperlukan dalam upaya menurunkan kemiskinan. Data PBB menyatakan bahwa pada daerah pedesaan di negara berkembang terdapat sekitar 1 milyar penduduk dari 1,2 milyar penduduk hidup dalam kemiskinan absolute (absolute proverty).

Sektor pertanian memiliki peranan yang besar dalam perekonomian, terutama di tahaptahap awal pembangunan. Sektor pertanian yang tumbuh dan menghasilkan surplus yang besar merupakan prasyarat untuk memulai proses transformasi ekonomi. Sektor non-pertanian, umumnya terlalu kecil untuk melakukan peranan itu. Pertanian pertama harus mampu mengatasi kendala pangan yang sering dihadapi negara-negara berkembang. Selama kendala pangan ini masih ada, maka pembangunan sektor non-pertanian akan terhambat.

\section{Sektor Pertanian dalam Perspektif Islam}

Zaman sekarang kita dihadapkan pada banyaknya jenis dan macam pekerjaan. Pekerjaan atau mata pencaharian seseorang kian bertambahnya penduduk dan semakin khususnya keahlian seseorang. Namun sebenarnya pada asalnya hanya ada tiga profesi sebagaimana disebutkan oleh iman Al-Mawardi. Dia berkata "Pokok mata pencaharian tersebut adalah bercocok tanam (pertanian), perdagangan, dan pembuatan suatu barang (industri)".Para ulama berselisih tentang manakah yang paling baik dari ketiga profesi tersebut. Mazhab berpendapat bercocok tanamlah yang paling baik karena beberapa alasan, yaitu:

1. Bercocok tanam merupakan hasil usaha tangan sendiri. Dalam shohih Al-Bukhori dari Miqdam bin Ma'dinkariba r.a dari Nabi SAW.

2. Bercocok tanam memberikan manfaat yang umum bagi kaum muslimin bahkan binatang. Secara adat manusia dan binatang haruslah makan, dan makanan tersebut tidaklah diperoleh melainkan dari hasil tanaman dan tumbuhan.

\section{METODE PENELITIAN}

Penelitian ini menggunakan metode analisis deskriptif kuantitatif yakni memberikan gambaran yang sistematis berdasarkan data yang ada dimana peneliti tidak hanya memanfaatkan data saja akan tetapi menganalisa dan menginterpretasikan data tersebut.

Penelitian kuantitatif merupakan penelitian yang lebih menekankan pada aspek pengukuran secara obyektif terhadap fenomena sosial. Untuk dapat melakukan pengukuran, setiap fenomena sosial di jabarkan kedalam beberapa komponen masalah, variabel dan indikator. Penelitian deskriptif adalah metode yang berfungsi untuk mendeskripsikan atau memberi gambaran terhadap objek yang diteliti melalui data atau sampel yang telah terkumpul sebagaimana adanya, tanpa melakukan analisis dan membuat analisis dan membuat kesimpulan yang berlaku. 
Penelitian ini dilaksanakan di Kabupaten Dairi tepatnya di Kantor Dinas Pertanian Kabupaten Dairi Jl. Pahlawan No. 96, Batang Beruh, Sidikalang dan di Kantor Badan Pusat Statistik Kabupaten Dairi Jl. Pelita No. 15, Batang Beruh, Sidikalang dengan pertimbangan bahwa Kabupaten Dairi sangat potensial dalam perkembangan sektor pertanian. Data yang digunakan dalam penelitian ini merupakan laporan data PDRB Kabupaten Dairi dan sektor pertanian pertanian yang dikeluarkan oleh Badan Pusat Statistik (BPS) Kabupaten Dairi.

Teknik analisis data yang digunakan dalam penelitian ini dengan menggunakan metode analisis kontribusi dan analisis trend kuadrat terkecil(least square method). Analisis kontribusi yaitu analisis yang digunakan untuk mengetahui seberapa besar kontribusi dapat disumbangkan dari output setiap subsektor pertanian terhadap sektor pertanian dan kontribusi sektor pertanian terhadap Produk Domestik Regional Bruto (PDRB) di Kabupaten Dairi. Sedangkan metode trend kuadrat terkecil (least square method) bertujuan untuk mengetahui perubahan nilai suatu variabel dari waktu ke waktu. Metode ini untuk mengukur pertumbuhan Produk Domestik Regional Bruto (PDRB) pada sektor pertanian di Kabupaten Dairi.

Besaran kontribusi sektor pertanian yang dimaksud dirumuskan dalam persamaan sebagai berikut:

Keterangan:

$$
\mathrm{KSP}=(\mathrm{PDRBsp} / \mathrm{PDRBtot}) \times 100 \%
$$

PDRBsp

: Kontribusi sektor pertanian pada tahun tertentu

PDRBtot

: PDRB sektor pertanian pada tahun tertentu

: PDRB total Kabupaten Dairi pada tahun tertentu

Kecenderungan pertumbuhan PDRB sektor pertanian di Kabupaten Dairi selama periode pengamatan akan diformulasikan dalam persamaan:

\begin{tabular}{|c|c|}
\hline & $\begin{array}{l}Y=a+b X \\
b=\sum(X i . Y i) / \sum(X i) 2, a=\sum(Y i) / n\end{array}$ \\
\hline \multicolumn{2}{|c|}{ keterangan: } \\
\hline Y & : Persentase nilai proyeksi pertumbuhan kontribusi sektor pertanian \\
\hline$h$ & : Rata-rata peningkatan kontribusi sektor pertanian tahun pengamatar \\
\hline & : Rata-rata persentase kontribusi sektor pertanian tahun pengamatan \\
\hline & : Series \\
\hline & : Persentase kontribusi sektor pertanian pada tahun ke-i \\
\hline & : Jumlah tahun pengamatan \\
\hline
\end{tabular}

\section{HASIL DAN PEMBAHASAN}

Hasil Analisis Kontribusi

Analisis Kontribusi Subsektor Tanaman Pangan terhadap Sektor Pertanian Kabupaten Dairi

Tabel 4. Kontribusi Subsektor Tanaman Pangan terhadap Sektor Pertanian Kabupaten Dairi Tahun 2016-2020 (Juta Rupiah)

\begin{tabular}{|c|c|c|c|c|}
\hline Tahun & TnP & PDRBsp & TnP : PDRBsp & KSP (Persen) \\
\hline 1 & 2 & 3 & $4=(2):(3)$ & $5=(4) \times 100 \%$ \\
\hline 2016 & $782.055,40$ & $2.617 .956,40$ & 0,30 & 29,87 \\
\hline 2017 & $828.767,10$ & $2.726 .369,00$ & 0,30 & 30,40 \\
\hline 2018 & $872.437,60$ & $2.838 .868,00$ & 0,31 & 30,73 \\
\hline 2019 & $913.250,90$ & $2.942 .507,50$ & 0,31 & 31,04 \\
\hline 2020 & $904.956,90$ & $2.940 .990,20$ & 0,31 & 30,77 \\
\hline & & & Jumlah & 152,81 \\
\hline & & & Rata-rata & 30,56 \\
\hline
\end{tabular}

Sumber: Badan Pusat Statistik Kabupaten Dairi Data Diolah 
Tabel 4. menunjukkan bahwa kontribusi subsektor tanaman pangan terhadap sektor pertanian Kabupaten Dairi dari tahun 2016-2019 mengalami kenaikan sedangkan pada tahun 2020 mengalami penurunan. Secara umum selama lima tahun pengamatan dari tahun 2016-2020, ratarata kontribusi kontribusi subsektor pertanian terhadap sektor pertanian Kabupaten Dairi sebesar 30,56\% dari total kontribusi subsektor pertanian terhadap sektor pertanian Kabupaten Dairi. Ini menunjukkan bahwa kontribusi subsektor tanaman pangan terhadap sektor pertanian Kabupaten Dairi memberikan kontribusi terbesar terhadap sektor pertanian Kabupaten Dairi dibandingkan subsektor pertanian yang lain.

\section{Analisis Kontribusi Subsektor Perkebunan terhadap Sektor Pertanian Kabupaten Dairi}

Tabel 5. Kontribusi Subsektor Perkebunan terhadap Sektor Pertanian Kabupaten Dairi Tahun 20162020 (Juta Rupiah)

\begin{tabular}{|c|c|c|c|c|}
\hline Tahun & Pkb & PDRBsp & Pkb : PDRBsp & KSP (Persen) \\
\hline 1 & 2 & 3 & $4=(2):(3)$ & $5=(4) \times 100 \%$ \\
\hline 2016 & $586.464,00$ & $2.617 .956,40$ & 0,22 & 22,40 \\
\hline 2017 & $612.315,00$ & $2.726 .369,00$ & 0,22 & 22,46 \\
\hline 2018 & $644.707,50$ & $2.838 .868,00$ & 0,23 & 22,71 \\
\hline 2019 & $679.392,80$ & $2.942 .507,50$ & 0,23 & 23,09 \\
\hline 2020 & $685.935,40$ & $2.940 .990,20$ & 0,23 & 23,32 \\
\hline & & & Jumlah & 22,80 \\
\hline & & & Rata-rata & 113,98 \\
\hline
\end{tabular}

Sumber: Badan Pusat Statistik Kabupaten Dairi Data Diolah

Tabel 5. menunjukkan bahwa kontribusi subsektor perkebunan terhadap sektor pertanian Kabupaten Dairi tahun 2016-2020 selalu mengalami kenaikan. Secara umum selama lima tahun pengamatan dari tahun 2016 sampai dengan tahun 2020, rata-rata kontribusi subsektor perkebunan terhadap sektor pertanian Kabupaten Dairi sebesar 22,80\%. Data ini menunjukkan bahwa kontribusi yang diberikan subsektor perkebunan terhadap sektor pertanian setiap tahun mengalami kenaikan.

\section{Analisis Kontribusi Subsektor Peternakan terhadap Sektor Pertanian Kabupaten Dairi}

Tabel 6. Analisis Kontribusi Subsektor Peternakan terhadap Sektor Pertanian Kabupaten Dairi Tahun 2016-2020 (Juta Rupiah)

\begin{tabular}{|c|c|c|c|c|}
\hline Tahun & Ptk & \multicolumn{1}{|c|}{ PDRBsp } & Ptk : PDRBsp & \multicolumn{1}{|c|}{ KSP (Persen) } \\
\hline 1 & 2 & 3 & $4=(2):(3)$ & $5=(4) \times 100 \%$ \\
\hline 2016 & $117.735,50$ & $2.617 .956,40$ & 0,04 & 4,50 \\
\hline 2017 & $124.467,10$ & $2.726 .369,00$ & 0,05 & 4,57 \\
\hline 2018 & $131.096,60$ & $2.838 .868,00$ & 0,05 & 4,62 \\
\hline 2019 & $130.403,90$ & $2.942 .507,50$ & 0,04 & 4,43 \\
\hline 2020 & $127.261,20$ & $2.940 .990,20$ & 0,04 & 22,44 \\
\hline & & & Jumlah & 4,49 \\
\hline
\end{tabular}

Sumber: Badan Pusat Statistik Kabupaten Dairi Data Diolah

Tabel 6. menunjukkan bahwa kontribusi subsektor peternakan terhadap sektor pertanian Kabupaten Dairi tahun 2016-2018 mengalami kenaikan dan tahun 2019 dan 2020 mengalami penurunan. Secara umum, rata-rata kontribusi yang diberikan subsektor peternakan terhadap 
sektor pertanaian Kabupaten Dairi selama lima tahun pengamatan dari tahun 2016-2020 sebesar $4,49 \%$.

\section{Analisis Kontribusi Subsektor Perikanan terhadap Sektor pertanian Kabupaten Dairi}

Tabel 7. Analisis Kontribusi Subsektor Perikanan terhadap Sektor Pertanian Kabupaten Dairi Tahun 2016-2020 (Juta Rupiah)

\begin{tabular}{|c|c|c|c|c|}
\hline Tahun & Pkn & PDRBsp & Pkn : PDRBsp & KSP (Persen) \\
\hline 1 & 2 & 3 & $4=(2):(3)$ & $5=(4) \times 100 \%$ \\
\hline 2016 & $118.796,60$ & $2.617 .956,40$ & 0,05 & 4,54 \\
\hline 2017 & $122.512,10$ & $2.726 .369,00$ & 0,04 & 4,49 \\
\hline 2018 & $125.968,10$ & $2.838 .868,00$ & 0,04 & 4,44 \\
\hline 2019 & $128.890,60$ & $2.942 .507,50$ & 0,04 & 4,38 \\
\hline 2020 & $130.843,00$ & $2.940 .990,20$ & 0,04 & 4,45 \\
\hline & & & Jumlah & 22,30 \\
\hline & & & Rata-rata & 4,46 \\
\hline
\end{tabular}

Sumber: Badan Pusat Statistik Kabupaten Dairi Data Diolah

Tabel 7. menunjukkan bahwa kontribusi subsektor perikanan terhadap sektor pertanian Kabupaten Dairi tahun 2016-2019 mengalami penurunan namun pada tahun 2020 mengalami kenaikan. Secara umum selama lima tahun pengamatan dari tahun 2016-2020, rata-rata kontribusi subsektor perikanan sebesar 4,46 dari total nilai sektor pertanian Kabupaten Dairi.

Analisis Kontribusi Subsektor Kehutanan terhadap Sektor Pertanian Kabupaten Dairi

Tabel 8. Analisis Kontribusi Subsektor Kehutanan terhadap Sektor Pertanian Kabupaten Dairi Tahun 2016-2020 (Juta Rupiah)

\begin{tabular}{|c|c|c|c|r|}
\hline Tahun & Khn & PDRBsp & Khn : PDRBsp & \multicolumn{1}{|c|}{ KSP (Persen) } \\
\hline 1 & 2 & 3 & $4=(2):(3)$ & $5=(4) \times 100 \%$ \\
\hline 2016 & $214.513,20$ & $2.617 .956,40$ & 0,08 & 8,19 \\
\hline 2017 & $214.966,00$ & $2.726 .369,00$ & 0,08 & 7,88 \\
\hline 2018 & $215.725,40$ & $2.838 .868,00$ & 0,08 & 7,60 \\
\hline 2019 & $216.113,70$ & $2.942 .507,50$ & 0,07 & 7,34 \\
\hline 2020 & $219.416,30$ & $2.940 .990,20$ & & 0,07 \\
\hline & & & Jumlah & 38,48 \\
\hline & & & Rata-rata & 7,70 \\
\hline
\end{tabular}

Sumber: Badan Pusat Statistik Kabupaten Dairi Data Diolah

Tabel 8. menunjukkan bahwa kontribusi subsektor kehutanan terhadap sektor pertanian Kabupaten Dairi dari tahun 2016-2019 mengalami penurunan sedangkan tahun 2020 mengalami kenaikan. Secara umum selama lima tahun pengamatan dari tahun 2016 sampai dengan tahun 2020, rata-rata kontribusi subsektor kehutanan 7,70\% dari total nilai sektor pertanian di Kabupaten Dairi. 
p-ISSN 2798-0499 e-ISSN 2798-0502

Analisis Kontribusi Sektor Pertanian terhadap PDRB Kabupaten Dairi

Tabel 9. Analisis Kontribusi Sektor Pertanian terhadap Produk Domestik Regional Bruto Kabupaten Dairi Tahun 2016-2020 (Juta Rupiah)

\begin{tabular}{|c|c|c|c|c|}
\hline Tahun & PDRBsp & PDRBtot & PDRBsp : PDRBtot & KSP (Persen) \\
\hline 1 & 2 & 3 & $4=(2):(3)$ & $5=(4) \times 100 \%$ \\
\hline 2016 & $2.617 .956,40$ & $5.688 .450,92$ & 0,46 & 46,02 \\
\hline 2017 & $2.726 .369,00$ & $5.968 .806,17$ & 0,46 & 45,68 \\
\hline 2018 & $2.838 .868,00$ & $6.267 .821,65$ & 0,45 & 45,29 \\
\hline 2019 & $2.942 .507,50$ & $6.569 .813,11$ & 0,45 & 44,79 \\
\hline 2020 & $2.940 .990,20$ & $6.508 .053,01$ & 0,45 & 45,19 \\
\hline & & & Jumlah & 226,97 \\
\hline & & & Rata-rata & 45,39 \\
\hline
\end{tabular}

Sumber: Badan Pusat Statistik Kabupaten Dairi Data Diolah

Tabel 9. menunjukkan bahwa kontribusi sektor pertanian terhadap pembentukan Produk Domestik Regional Bruto (PDRB) Kabupaten Dairi mengalami fluktuatif selama lima tahun pengamatan dari tahun 2016-2020. Secara umum, selama lima tahun pengamatan dari tahun 2016 sampai tahun 2020, rata-rata kontribusi sektor pertanian sebesar $45,39 \%$ dari total PDRB Kabupaten Dairi. Hal ini menunjukkan bahwa sektor pertanian di Kabupaten Dairi merupakan sektor yang memberikan kontribusi terbesar terhadap pembentukan PDRB di Kabupaten Dairi dibandingkan sektor perekonomian lainnya di Kabupaten Dairi, namun kontribusi yang diberikan sektor pertanian terhadap PDRB Kabupaten Dairi selama lima tahun pengamatan mengalami penurunan dari tahun 2016-2019 sedangkan tahun 2020 kembali mengalami kenaikan.

\section{Analisis Trend Kuadrat Terkecil (Least Square Method)}

Pertumbuhan sektor pertanian terhadap Produk Domestik Regional Bruto (PDRB) Kabupaten Dairi dianalisis dengan menggunakan analisis trend kuadrat terkecil (least square method) linear untuk melihat proyeksi kontribusi sektor pertanian terhadap Produk Domestik Regional Bruto (PDRB) Kabupaten Dairi lima tahun kedepan dari dari data Produk Domestik Regional Bruto Kabupaten Dairi tahun 2016-2020 menurut harga konstan tahun dasar tahun 2010. Tabel 10. Analisis Trend Kuadrat Terkecil (Least Square Method) pada Produk Domestik Regional Bruto Sektor Pertanian Kabupaten Dairi

Tabel 10. Analisis Trend Kuadrat Terkecil (Least Square Method) pada Produk Domestik Regional Bruto Sektor Pertanian Kabupaten Dairi

\begin{tabular}{|c|c|c|c|c|}
\hline Tahun & Proyeksi $(Y)$ & Series $(X)$ & $(X) \times(Y)$ & $X^{2}$ \\
\hline 2016 & 46,02 & -2 & $-92,04$ & 4 \\
\hline 2017 & 45,68 & -1 & $-45,68$ & 1 \\
\hline 2018 & 45,29 & 0 & 0 & 0 \\
\hline 2019 & 44,79 & 1 & 44,79 & 1 \\
\hline 2020 & 45,19 & 2 & 90,38 & 4 \\
\hline Jumlah & 226,97 & 0 & $-2,55$ & 10 \\
\hline Rata-rata (a) & 45,39 & & & \\
\hline (b) & $-0,26$ & & & \\
\hline
\end{tabular}

Sumber: Badan Pusat Statistik Kabupaten Dairi Data Diolah

Dari tabel 10. diperoleh nilai $a=45,39$ dan $b=-0,26$ sehingga secara umum persamaan trend nilai proyeksi kontribusi sektor pertanian terhadap Produk Domestik Regional Bruto (PDRB)

266 | Marliyah, Muhammad Syahbudi, Lisna Limbong; Analysis of the Contribution of... 
Kabupaten Dairi dapat diperoleh dengan rumus $Y=45,39-0,26 X$. Untuk lebih jelasnya dapat dilihat pada tabel 11.

Tabel 11. Proyeksi Pertumbuhan Kontribusi Sektor Pertanian terhadap Produk Domestik Regional Bruto Kabupaten Dairi

\begin{tabular}{|c|c|c|c|c|}
\hline Tahun & Proyeksi $(Y)$ & Series $(X)$ & $(X) \times(Y)$ & $X^{2}$ \\
\hline 2016 & 46,02 & -2 & $-92,04$ & 4 \\
\hline 2017 & 45,68 & -1 & $-45,68$ & 1 \\
\hline 2018 & 45,29 & 0 & 0 & 0 \\
\hline 2019 & 44,79 & 1 & 44,79 & 1 \\
\hline 2020 & 45,19 & 2 & 90,38 & 4 \\
\hline Jumlah & 226,97 & 0 & $-2,55$ & 10 \\
\hline Rata-rata (a) & 45,39 & & & \\
\hline (b) & $-0,26$ & \multicolumn{3}{|r|}{} \\
\hline
\end{tabular}

Sumber: Badan Pusat Statistik Kabupaten Dairi Data Diolah

Hasil analisis pertumbuhan sektor pertanian terhadap PDRB Kabupaten Dairi dengan menggunakan metode trend kuadrat terkecil (least square method) seperti pada tabel 8 menunjukkan bahwa pada tahun 2021 pertumbuhan sektor pertanian sebesar 44,63\% lebih rendah dari tahun 2020 yaitu 44,88\%. Pertumbuhan sektor pertanian pada tahun 2022 sebesar 44,37\%, tahun 2023 sebesar 44,12, tahun 2024 sebesar 43,86\% hingga tahun 2025 pertumbuhan sektor pertanian mengalami penurunan dari tahun 2024 yaitu 43,61\%. Hal ini menunjukkan proyeksi pertumbuhan sektor pertanian terhadap PDRB Kabupaten Dairi tahun 2021-2025 terus mengalami penurunan.

Secara umum selama lima tahun pengamatan yaitu tahun 2016-2020, proyeksi pertumbuhan kontribusi sektor pertanian terhadap Produk Domestik Regional Bruto (PDRB) Kabupaten Dairi berdasarkan analisis trend kuadrat terkecil (least square method) yaitu $Y=45,39-$ 0,26X. Hasil ini juga memproyeksikan pertumbuhan kontribusi sektor pertanian terhadap Produk Domestik Regional Bruto (PDRB) Kabupaten Dairi untuk lima tahun kedepan dengan proyeksi pertumbuhan kontribusi sektor pertanian pada tahun 2025 sebesar 43,61\%.

\section{KESIMPULAN DAN SARAN}

\section{Kesimpulan}

Hasil penelitian dan pembahasan, maka dapat dinyatakan bahwa kontribusi sektor pertanian terhadap Produk Domestik Regional Bruto (PDRB) Kabupaten Dairi selama lima tahun pengamatan yaitu tahun 2016-2020, rata-rata kontribusi subsektor tanaman pangan sebesar 30,56\% dari total nilai sektor pertanian Kabupaten Dairi, rata-rata kontribusi subsektor perkebunan sebesar $22,80 \%$ dari total nilai sektor pertanian Kabupaten Dairi, rata-rata kontribusi subsektor peternakan sebesar $4,49 \%$ dari total nilai sektor pertanian Kabupaten Dairi, rata-rata kontribusi subsektor perikanan sebesar 4,46 dari total nilai sektor pertanian Kabupaten Dairi, dan rata-rata kontribusi subsektor kehutanan sebesar 7,70\% dari total nilai sektor pertanian Kabupaten Dairi.

Kontribusi sektor pertanian terhadap Produk Domestik Regional Bruto (PDRB) Kabupaten Dairi selama lima tahun pengamatan yaitu tahun 2016-2020, rata-rata kontribusi sektor pertanian sebesar 45,39\% dari total PDRB Kabupaten Dairi. Serta proyeksi pertumbuhan kontribusi sektor pertanian terhadap Produk Domestik Regional Bruto (PDRB) Kabupaten Dairi melalui analisis trend kuadrat terkecil (least square method) yaitu $Y=45,39-0,26 X$. Hasil ini juga memproyeksikan pertumbuhan kontribusi sektor pertanian terhadap Produk Domestik Regional Bruto (PDRB) Kabupaten Dairi untuk lima tahun kedepan dengan proyeksi pertumbuhan kontribusi sektor pertanian pada tahun 2025 sebesar $43,61 \%$. 


\section{Saran}

1. Kepada semua pihak terutama pemerintah agar lebih meningkatkan perhatian terhadap sektor pertanian di Kabupaten Dairi untuk menunjang peningkatan kontribusi sektor pertanian terhadap PDRB Kabupaten Dairi yang mengakselerasi peningkatan kesejahteraan masyarakat dan penyerapan tenaga kerja, karena dari hasil penelitian sektor pertanian merupakan sektor yang memberikan kontribusi terbesar terhadap pembentukan nilai Produk Domestik Regional Bruto Kabupaten Dairi.

2. Untuk pengembangan ilmu lebih lanjut, pada penelitian selanjutnya disarankan menggunakan metode analisis lain seperti analisis Location Quotient, Dynamic Location Quotient dan Shift Share untuk mengetahui sektor pertanian menjadi sektor basis dalam pertanian dan mengidentifikasi subsektor pertanian yang menjadi subsektorbasis.

\section{DAFTAR PUSTAKA}

Arsyad, Lincolin. Ekonomi Pembangunan Edisi Ke-5, Yogyakarta: UPP STIM YKPM, 2010

Bi Rahmadi, Nur Ahmadi.Metode Penelitian Ekonomi, Medan: FEBI UIN-SU Press, 2016

Dumairy. Perekonomian Indonesia, Jakarta: Erlangga, 2017

Harahap, Isnaini. Ekonomi Pembangunan Pendekatan Transdisipliner, Medan: Perdana Publishing, 2018

Harahap, Isnaini. Yenni Samri Juliati Nasution, Marliyah.Hadis-Hadis Ekonomi, Medan: Wal Ashri Pulishing, 2015

Huda, Nurul, dkk. Ekonomi Pembangunan Islam, Jakarta: Kencana, 2015

Imsar."Analisis Produksi dan Pendapatan Usaha Tani Kopi Gayo (Arabika) Kabupaten Bener Meriah Studi Kasus : Desa Pantan Tengah Kecamatan Permata". Laporan Penelitian, Fakultas Ekonomi dan Bisnis Islam Universitas Islam Negeri Sumatera Utara, 2018

Kuncoro, Mudrajad. Ekonomi Pembangunan: Teori, Masalah, dan Kebijakan, Sleman: Unit Penerbitan dan Percepatan, Akademi Manajemen Perusahaan YKPN, 1997

Maisaroh, Siti. "Analisis Peranan dan Kontribusi Sektor Pertanian Terhadap Pertumbuhan Wilayah dalam Perspektif Ekonomi Islam (Studi Pada Kabupaten Tulang Bawang)". Skripsi, Fakultas Ekonomi dan Bisnis Islam UIN Raden Intan Lampung, 2017

Rahman, Abdul. Adam Malik, Andi dan Sahabuddin Toaha. "Analisis Kontribusi Sektor Pertanian Terhadap Produk Domestik Regional Bruto Kota Parepre". Jurnal Agribisnis Perikanan. Vol.12 No. 2. 2019

Rasyid, Abdurahman. Analisis Potensi Pertanian di Kabupaten Kediri Tahun 2010-2014.Jurnal Ekonomi Pembangunan Vol. 14, No. 02. 2016

Risnawati. "Kontribusi Sektor Pertanian Terhadap Produk Domestik Regional Bruto (PDRB) di Kabupaten Jeneponto". Skripsi, Fakultas Ekonomi dan Bisnis Islam Universitas Islam Negeri Alauddin Makassar, 2016

Sattar. Buku Ajar Perekonomian Indonesia, Yogyakarta: Deepublish, 2018.

268 | Marliyah, Muhammad Syahbudi, Lisna Limbong; Analysis of the Contribution of... 